\title{
The words of prevention, part II: ten terms in the realm of quaternary prevention
}

\author{
As palavras da prevenção, parte II: dez termos no âmbito da prevenção quaternária
}

\section{Las palabras de la prevención, parte Il: diez términos en el ámbito de la prevención cuaternaria}

Marc Jamoulle. Family doctor. Department of General Practice, University of Liège. Belgium. marc.jamoulle@doct.ulg.ac.be (Corresponding author) Enrique Gavilán. Family and Community doctor. Centro de Salud Montehermoso. Cáceres, España. enrique.gavilan.moral@gmail.com Raquel Vaz Cardoso. Family and Community doctor. Universidade de Brasília (UnB). Brasília, DF, Brasil. raquelvc.mfc@gmail.com María Ana Mariño. Family doctor. Sociedad Argentina de Medicina Interna General (SAMIG). Buenos Aires, Argentina. marian_marino@yahoo.com.ar Miguel Pizzanelli. Family and Community doctor. Unidad docente asistencial rural de Florida. Florida, Uruguay. miguelpizzanelli@gmail.com Julien Grosjean. Engineer \& Information scientist, CISMeF, TIBS, LITIS EA 4108. Rouen University Hospital. Rouen, France. julien.grosjean@chu-rouen.fr Stéfan J. Darmoni. Professor of medical Informatics, CISMeF,TIBS, LITIS EA 4108. Rouen University Hospital. Rouen, France. stefan.darmoni@chu-rouen.fr

\section{Abstract}

Objective: this part II article about the 'words of prevention' presents in a terminological way the content of ten current concepts used in the prevention domain which are closely linked to quaternary prevention: (1) overinformation; (2) overdiagnosis; (3) medically unexplained symptoms; (4) overmedicalization; (5) incidentaloma; (6) overscreening; (7) overtreatment; (8) shared decision making; (9) deprescribing; and (10) disease mongering. Methods: with the support of the laboratory team of the University of Rouen, France, which is dedicated to medical terminology and semantic relationships, it was possible to utilize a graphic user interface (called DBGUI) allowing the construction of links for each of chosen terms, and making automatic links to MeSH, if any. Those concepts are analyzed in their environment in current literature, as well as in their MeSH counterparts, if any, and related semantic online terminologies. Results and Discussion: the rules in terminological development aspire to cover the whole field of a concept and in the meantime, they can help to avoid the noise due to proxy and not exactly related issues. This refers to exhaustivity and specificity in information retrieval. Our finds show that referring to MeSH only in information retrieval in General Practice/Family medicine can induce much noise and poor adequacy to the subject investigated. Conclusion: gathering concepts in specially prepared terminologies for further development of ontologies is a necessity to enter in the semantic web area and the era of disseminated data in family medicine.

\section{Resumo}

Objetivo: este artigo parte II sobre as 'palavras da prevenção' apresenta de uma forma terminológica o conteúdo de dez conceitos atuais utilizados no domínio da prevenção, que estão intimamente ligados à prevenção quaternária: (1) sobrecarga de informação; (2) sobrediagnóstico; (3) sintomas sem explicação médica; (4) sobremedicalização; (5) incidentaloma; (6) sobrerrastreamento; (7) sobretratamento; (8) tomada de decisão compartilhada; (9) desprescrição; e (10) comercialização de doenças. Métodos: com o apoio da equipe do laboratório da Universidade de Rouen, França, que se dedica à terminologia médica e às relações semânticas, foi possivel utilizar uma interface gráfica de usuário (chamado DBGUI) permitindo a construção de links para cada um dos termos escolhidos, fazendo ligações automáticas para o MeSH, caso houvesse. Estes conceitos foram analisados no seu ambiente na literatura corrente, bem como os seus homólogos no MeSH, caso houvesse, e terminologias semânticas online a eles relacionadas. Resultados e Discussão: as regras em desenvolvimento terminológico aspiram cobrir todo o campo de um conceito, ao mesmo tempo em que podem auxiliar a evitar ruídos devido a aproximações e questões não exatamente relacionadas. Isto se refere à exaustividade e especificidade na recuperação da informação. Nossos achados mostram que referir-se somente ao MeSH na recuperação de informação em medicina de família pode induzir muito ruídos e uma pobre adequação em relação ao tema investigado. Conclusão: reunir conceitos em terminologias especialmente preparadas para um maior desenvolvimento de ontologias é uma necessidade para se adentrar na área da rede semântica e da era de dados disseminados em medicina de família.

\section{Keywords:} Quaternary Prevention Family Practice Terminology as Topics Semantics

\section{Palavras-chave:}

Prevenção Quaternária Medicina de Família e Comunidade Terminologia como Assunto Semântica 


\section{Resumen}

Objetivo: este artículo parte II de las 'palabras de prevención' presenta en una forma terminológica el contenido de diez conceptos actuales utilizados en el dominio de la prevención que están estrechamente vinculados a la prevención cuaternaria: (1) sobreinformación; (2) sobrediagnóstico; (3) síntomas sin explicación médica; (4) sobremedicalización; (5) incidentaloma; (6) sobretamizaje; (7) sobretratamiento; (8) toma de decisiones compartida; (9) deprescripción; y (10) tráfico de enfermedades. Métodos: con el apoyo del equipo de laboratorio de la Universidad de Rouen, Francia, que se dedica a la terminología médica y las relaciones semánticas, fue posible utilizar la interfaz gráfica de usuario (Ilamado DBGUI) permitiendo la construcción de enlaces para cada uno de los términos elegidos, y estableciendo vínculos automáticos al MeSH, en su caso. Esos conceptos fueran analizados en el contexto de la literatura actual, así como en sus homólogos MeSH, en su caso, y terminologías semánticos relacionados online. Resultados y Discusión: las reglas en el desarrollo terminológico aspiran a cubrir la totalidad del ámbito del concepto y, mientras tanto, ayudan a evitar el ruido debido al proxy y temas no relacionados con exactitud. Esto se refiere a la exhaustividad y especificidad en la recuperación de informaciones. Nuestros hallazgos muestran que al referir-se solamente al MeSH la recuperación de información en Medicina General/Medicina Familiar puede inducir a mucho ruidos y mala adecuación al tema investigado. Conclusión: la recopilación de conceptos en terminologías especialmente preparados para un mayor desarrollo de ontologías es una necesidad para entrar en el área de la web semántica y en la era de los datos diseminados en medicina familiar.
Palabras clave:

Prevención Cuaternaria

Medicina Familiar y Comunitaria Terminología como Asunto Semántica

\section{Introduction}

There are striking differences in the world of reference ${ }^{1,2}$ of General Practice/Family Medicine comparing to those of academic and other specialized branches of medicine. These differences started to be addressed in the part I of this paper. The part I article identified some of the main words of prevention, representing the $\mathrm{P} 4$ paradigmatic shift from a chronological based prevention towards a constructivist view based on patient-doctor relationships. It also discussed words such as clinical prevention, primary prevention, secondary prevention, tertiary prevention, and quaternary prevention.

This part II article discusses other P4 related concepts such as overinformation, overdiagnosis, medically unexplained symptoms, overmedicalisation, incidentaloma, overscreening, overtreatment, shared decision making, deprescribing and disease mongering. Since family doctors do not use the same wording as patients, librarians or focal medical specialists (consultants), there is a need for disambiguation of meanings, which rules health information retrieval and consequently high-precision information retrieval tools are needed. ${ }^{3}$ As a by-product of patient-doctor relationships, quaternary prevention encompasses concepts that, each of them deals with ethical issues in day to day medicine. These concepts are the focus of this paper as shown in Table 1 .

Table 1. Ten terms related to quaternary prevention in the Q-Codes list available online. ${ }^{4}$

\begin{tabular}{lllll}
\hline QD44 & Quaternary Prevention & Prévention Quaternaire & Prevención Cuaternaria & Prevenção Quaternária \\
\hline QD440 & overinformation & surinformation & exceso de información & sobrecarga de informação \\
QD441 & medically unexplained symptom & symptôme médicalement inexpliqué & síntoma sin explicación médica & sintoma sem explicação médica \\
QD442 & overmedicalisation & surmédicalisation & sobremedicalización & sobremedicalização \\
QD443 & deprescription & déprescription & deprescripción & desprescrição \\
QD444 & shared decision making & prise de décision partagée & toma de decisiones compartida & tomada de decisão compartilhada \\
QD445 & incidentaloma & fortuitome & incidentaloma & incidentaloma \\
QD446 & disease mongering & fabrication de maladie & tráfico de enfermedades & comercialização de doenças \\
QD447 & overscreening & surdépistage & sobretamizaje & sobrerrastreamento \\
QD448 & overtreatment & surtraitement & sobretratamiento & sobretratamento \\
QD449 & overdiagnosis & surdiagnostic & sobrediagnóstico & sobrediagnóstico \\
\hline
\end{tabular}

Source: elaborated by the authors, 2015.

Retrieving literature with existing MeSH descriptors can be sometimes a big challenge for the above incisive concepts in the field of GP/FM. ${ }^{5}$ Hence, we have decided to explore the literature about those domains (Table 1) and report the most popular words in Family Medicine, echoing the research in the same domain by epidemiologists and hospital based specialists. ${ }^{6}$ The help of the Rouen Institute for Research and Innovation in Biomedicine team ${ }^{7}$ has been seminal in developing the relationships of those concepts with the appropriate methods, paving the way of health care semantics. 
The impact of computer science on terminological issues is striking and family doctors have to understand that mastering the production and management of knowledge lies at their doorstep. They have to become familiar with semantic web technologies and related language processing as the computer will become omnipresent in their daily lives in a near future. For a GP, understanding health information gateways is as important as to understand Evidence-Based Medicine (EBM) or pharmacology. This paper highlights some basic steps necessary to master health information.

\section{Methods}

The computer laboratory of the University of Rouen, France, dedicated to medical terminology and semantic relationships, maintain 50 terminologies crossing website, linked by semantic web technologies under the URL of http://www.hetop.eu/ hetop/. ${ }^{8}$ The Medical Subject headings have been historically the first mapping of this semantic tool. The team of Rouen laboratory has put at disposal a graphic user interface, called DBGUI (Figure 1) allowing the construction of links for each chosen term and automatic link to $\mathrm{MeSH}$, if any. As stated in the first part of this paper, MeSH sometimes does not fully cover the field of GP/FM or proposed terms which content are historically marked. ${ }^{9}$ An external observer, expert in the domain of Family Medicine, has to verify the proposed links.

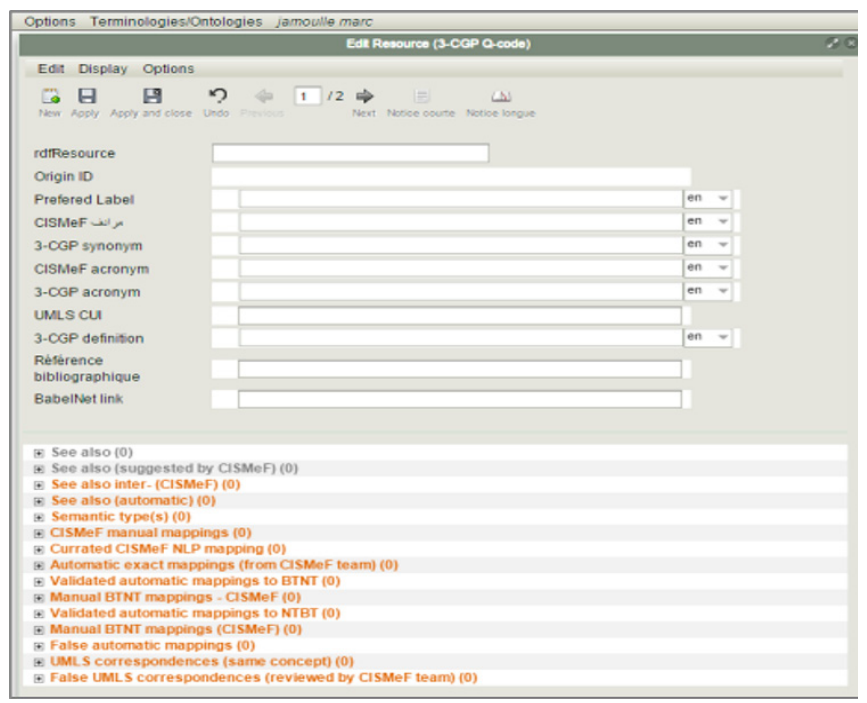

Figure 1. The DBGUI interface.

Source: Rouen computer laboratory. ${ }^{7}$

Gomes et al. have pointed out, in a paper on medical education in this special issue on P4, the vicious cycle identified in patient-doctor communication. The link between lay and professional terms is essential to enhance communication in primary care. This is the reason for the links of the DBGUI being completed with chosen links to Babelnet.org ${ }^{10}$ and to Dbpedia, ${ }^{11,12}$ one of the main nodes of the Linked data world ${ }^{13}$ and, consequently, with Wikipedia. ${ }^{14}$

Gathering concepts in specially prepared terminologies for further development of ontologies is a necessity to enter in the semantic web area and the era of disseminated data. ${ }^{15}$ The present results open the way to build a comprehensive set of main themes addressed by GPs during some conferences. ${ }^{16-18}$ Those concepts have been identified by one author (MJ) by a careful content analysis of more than 1600 abstracts of congresses of Family Medicine. This is an ongoing work and we 
have chosen to show the terminological content of ten out of 198 experimental descriptors referred as Q-Codes ${ }^{5}$ obtained by careful analysis of GP/FMs' congresses communications. The interface allows the user to build a terminological record by entering an ID (identification number) following by the Preferred label of a term, the synonyms and acronyms, if any, the most appropriate definition with bibliographic citation, the links to Babelnet.org and to Dbpedia or to other relevant semantic links. Internal links to already existing terminologies in hetop.eu can be chosen manually (in grey in the Figure 1) or automatically proposed by the interface which allows corrections (in red in the Figure 1). All the gathered data can be expressed in Web Ontology Language (OWL), ${ }^{19}$ the computer language used in the semantic web for Health Care and Life Sciences. ${ }^{20}$

Table 2. Ten terms related to quaternary prevention: links, definitions, sources and bibliographic citations, 2015.

\begin{tabular}{|c|c|}
\hline Q-Code & QD440 \\
\hline $\begin{array}{l}\text { Pref. Term } \\
\text { (PT) }\end{array}$ & Overinformation (health) \\
\hline Syn & Misinformation, fake information \\
\hline French PT & Surinformation \\
\hline Spanish PT & Exceso de información \\
\hline $\begin{array}{l}\text { Portuguese } \\
\text { PT }\end{array}$ & Sobrecarga de informação \\
\hline \multirow[t]{2}{*}{ MeSH } & $\begin{array}{l}\text { Qualifier needed: Information Dissemination/ethics* } \\
\text { The circulation or wide dispersal of information. }\end{array}$ \\
\hline & $\begin{array}{l}\text { Qualifier needed: Information Seeking Behavior/ethics* } \\
\text { How information is gathered in personal, academic or work environments and the resources used. }\end{array}$ \\
\hline Pubmed & 0 citation for "overinformation". 128,460 for "over information" (first in 1912) \\
\hline Syn & MUS \\
\hline French PT & Symptôme médicalement inexpliqué \\
\hline Spanish PT & Síntoma sin explicación médica \\
\hline $\begin{array}{l}\text { Portuguese } \\
\text { PT }\end{array}$ & Sintoma sem explicação médica \\
\hline
\end{tabular}


Table 2. Continued...

Medically Unexplained Symptoms (MUS) that may, or may not, be due to physical disease, which capture conditions characterized by symptoms without corresponding objective findings, often associated with high costs, both direct (health care use) and indirect costs (productivity loss due to sickness

Definition absence) such as asthenia, low back pain, fibromyalgia, irritable bowel syndrome, or chronic fatigue syndrome, as well as symptoms stemming from a specific somatic disease that is more severe, more persistent, or limit functioning to a greater extent than expected, based on (objective) disease parameters. Patients with MUS often experience significant disability and have difficulty accessing appropriate care (Adapted from Olde Hartman, 2013; Aamland et al., 2014; and Rask et al., 2015)

Olde Hartman TC, Woutersen-Koch H, Van der Horst HE. Medically unexplained symptoms: evidence, guidelines, and beyond. The British Journal of General Practice. 2013;63(617):625-626. doi:10.3399/bjgp13X675241.

Aamland A, Malterud K, Werner EL. Patients with persistent medically unexplained physical symptoms: a descriptive study from Norwegian general practice.BMC Fam Pract, 2014, 15(1):107doi:10.1186/1471-2296-15-107.

Bib. Citations Rask MT, Rosendal M, Fenger-Grøn M, Bro F, Ørnbøl E, Fink P. Sick leave and work disability in primary care patients with recent-onset multiple medically unexplained symptoms and persistent somatoform disorders: a 10-year follow-up of the FIP study. Gen Hosp Psychiatry, 2015;37(1):53-9. 10.1016/j. genhosppsych.2014.10.007

MeSH None

Pubmed 958 citations for "medically unexplained symptoms" (first 1980) 239 citations for "medically unexplained symptom" (first 1987) bn:03305496n

Babelnet Medically unexplained physical symptoms or medically unexplained symptoms are patient symptoms for which the treating physician, other healthcare providers, and research scientists have found no medical cause DBPedia http://dbpedia.org/page/Medically_unexplained_physical_symptoms

\begin{tabular}{|c|c|}
\hline Q-Code & QD442 \\
\hline $\begin{array}{l}\text { Pref. Term } \\
\text { (PT) }\end{array}$ & Overmedicalization \\
\hline Syn & Unnecessary health care, futile health care \\
\hline French PT & Surmédicalisation \\
\hline Spanish PT & Sobremedicalización \\
\hline $\begin{array}{l}\text { Portuguese } \\
\text { PT }\end{array}$ & Sobremedicalização \\
\hline Definition & $\begin{array}{l}\text { Overmedicalization - an excess of exposure to - or seeking for healthcare to an extent in which does not confer any benefit in terms of health and } \\
\text { welfare, directly related to the terms: overscreening, overdiagnosis, overtreatment (Cardoso, 2015). }\end{array}$ \\
\hline Bib. Citations & $\begin{array}{l}\text { Cardoso RV. Prevenção quaternária: um olhar sobre a medicalização na prática do médico de família. Rev Bras Med Fam Comunidade. } \\
\text { 2015;10(35):1117. Disponível em: http://dx.doi.org/10.5712/rbmfc10(35)1117 }\end{array}$ \\
\hline MeSH & $\begin{array}{l}\text { Partially related to: MeSH Medicalization } \\
\text { A process by which nonmedical problems become defined and treated as medical problems, usually in terms of illnesses, or disorders. (Annu Rev Sociol, } \\
1992 \text { 18:209) }\end{array}$ \\
\hline Pubmed & 12 citations for "overmedicalization" (first 1984) 6 for "overmedicalisation" (first in 2011) 140 for "over medicalization" (first 1979) \\
\hline & bn:15974546n \\
\hline Babelnet & $\begin{array}{l}\text { Unnecessary health care; } \\
\text { Unnecessary health care is health care provided with a higher volume or cost than is appropriate. }\end{array}$ \\
\hline DBPedia & http://dbpedia.org/page/Unnecessary_health_care \\
\hline Q-Code & QD443 \\
\hline $\begin{array}{l}\text { Pref. Term } \\
\text { (PT) }\end{array}$ & Deprescription (deprescribing) \\
\hline Syn & Drug utilization review (DUR) \\
\hline & Medication therapy management programs (MTM) \\
\hline French PT & Deprescription \\
\hline Spanish PT & Deprescripción \\
\hline $\begin{array}{l}\text { Portuguese } \\
\text { PT }\end{array}$ & Desprescrição \\
\hline
\end{tabular}


Table 2. Continued...

\begin{tabular}{cl}
\hline Q-Code & QD440 \\
\hline Definition & Drug utilization review (DUR) is defined as an authorized, structured, ongoing review of prescribing, dispensing and use of medication. DUR encompasses \\
& o drug review against predetermined criteria that results in changes to drug therapy when these criteria are not met. It involves a comprehensive review \\
& of patients' prescription and medication data before, during and after dispensing to ensure appropriate medication decision-making and positive patient \\
& Navarro R. Chapter 8: Drug utilization review strategies. In \\
& Managed Care Pharmacy Practice, pp. 215-229, 2008.
\end{tabular}

Bib. Citations Ai AL, Carretta H, Beitsch LM, Watson L, Munn J, Mehriary S. Medication Therapy Management Programs: Promises and Pitfalls. J Manag Care Spec Pharm. 2014;20(12):1162-82. http://www.ncbi.nlm.nih.gov/pubmed/25443511

Drug Utilization Review:

Assistance in managing and monitoring drug therapy for patients receiving treatment for cancer or chronic conditions such as asthma and diabetes, consulting with patients and their families on the proper use of medication; conducting wellness and disease prevention programs to improve public health; overseeing medication use in a variety of settings.

$\mathrm{MeSH}$ Medication Therapy Management:

Formal programs for assessing drug prescription against some standard. Drug utilization review may consider clinical appropriateness, cost effectiveness, and, in some cases, outcomes. Review is usually retrospective, but some analysis may be done before drugs are dispensed (as in computer systems which advise physicians when prescriptions are entered).

Pubmed 39 citations for "deprescribing" (first in 2007)

bn:16582550n

Babelnet Deprescribing is the process of tapering, withdrawing, discontinuing or stopping medications to reduce polypharmacy, adverse drug effects and inappropriate or ineffective medication use.

DBPedia http://dbpedia.org/page/Deprescribing

\begin{tabular}{ll}
\multicolumn{1}{c}{ Q-Code } & \\
\hline Pref. Term & QD 444 \\
(PT) & Shared decision making \\
Syn & SDM \\
French PT & Prise de décision partagée \\
Spanish PT & Toma de decisiones compartida \\
Portuguese & Tomada de decisão compartilhada \\
PT &
\end{tabular}

Under a shared decision making (SDM) process, health care practitioners and patients work together to make joint decisions about a patient's care. SDM

Definition requires that patients should be educated about and understand risks and benefits of their options. SDM is an important part of patient-centered care; education is often through the use of decision aids such as pamphlets, videos, and computerized tools. (Cochrane, Légaré, 2010).

Légaré F, Ratté S, Stacey D, Kryworuchko J, Gravel K, Graham ID, et al. Interventions for improving the adoption of shared decision making by healthcare

Bib. Citations professionals. Cochrane database Syst Rev. 2010; (5):CD006732. Available from: http://www.ncbi.nlm.nih.gov/pubmed/20464744

\begin{tabular}{|c|c|}
\hline & Wrongly related to: MeSH Decision Making \\
\hline MeSH & $\begin{array}{l}\text { The process of making a selective intellectual judgment when presented with several complex alternatives consisting of several variables, and usually } \\
\text { defining a course of action or an idea. }\end{array}$ \\
\hline \multirow{2}{*}{ Pubmed } & 189,688 citations for MeSH Decision making (first in 1952) \\
\hline & 2,882 for "shared decision making" \\
\hline \multirow[b]{2}{*}{ Babelnet } & bn:01657979n \\
\hline & $\begin{array}{l}\text { Shared decision-making is an approach where clinicians and patients communicate together using the best available evidence when faced with the } \\
\text { task of making decisions, where patients are supported to deliberate about the possible attributes and consequences of options, to arrive at informed } \\
\text { preferences in making a determination about the best action and which respects patient autonomy, where this is desired, ethical and legal. }\end{array}$ \\
\hline DBPedia & http://dbpedia.org/page/Shared_decision_making \\
\hline Q-Code & QD445 \\
\hline $\begin{array}{l}\text { Pref. Term } \\
\text { (PT) }\end{array}$ & Incidentaloma \\
\hline French PT & Fortuitome \\
\hline Spanish PT & Incidentaloma \\
\hline
\end{tabular}


Table 2. Continued...

\begin{tabular}{|c|c|}
\hline Q-Code & QD440 \\
\hline $\begin{array}{l}\text { Portuguese } \\
\text { PT }\end{array}$ & Incidentaloma \\
\hline Definition & $\begin{array}{l}\text { Incidentaloma: used to design an incidentally discovered mass, by chance, in an asymptomatic person, which probably never will harm his/her, not } \\
\text { excluding a real possibility of damage and a few chance of benefit. It is a form of overdiagnosis emerging from the massive use of high-resolution } \\
\text { diagnostic imaging. In many cases, it is associated with the increased rate of new diagnoses, causes anxiety, consumes time and resources, and can } \\
\text { even induce damage by the subsequent follow-up (Mariño M, 2015). }\end{array}$ \\
\hline Bib. Citation & $\begin{array}{l}\text { Mariño MA. Incidentalomas: concept, relevance and challenges for medical practice. Rev Bras Med Fam Comunidade. 2015;10(35):1053. Available at: } \\
\text { http://dx.doi.org/10.5712/rbmfc10(35)1053 }\end{array}$ \\
\hline $\mathrm{MeSH}$ & $\begin{array}{l}\text { Partially related to: Incidental findings } \\
\text { Unanticipated information discovered in the course of testing or medical care. Used in discussions of information that may have social or psychological } \\
\text { consequences, such as when it is learned that a child's biological father is someone other than the putative father, or that a person tested for one } \\
\text { disease or disorder has, or is at risk for, something else. }\end{array}$ \\
\hline Pubmed & 926 citations for “incidentaloma”(first 1982) \\
\hline Babelnet & $\begin{array}{l}\text { bn:03555265n } \\
\text { In medicine, an incidentaloma is a tumor found by coincidence without clinical symptoms or suspicion. }\end{array}$ \\
\hline DBPedia & http://live.dbpedia.org/page/Incidentaloma \\
\hline Q-Code & QD446 \\
\hline $\begin{array}{l}\text { Pref. Term } \\
\text { (PT) }\end{array}$ & Disease mongering \\
\hline French PT & Fabrication de maladie \\
\hline Spanish PT & Tráfico de enfermedades \\
\hline $\begin{array}{l}\text { Portuguese } \\
\text { PT }\end{array}$ & Comercialização de doenças \\
\hline Definition & $\begin{array}{l}\text { Disease mongering is the selling of sickness that widens the boundaries of illness in order to grow markets for those who sell and deliver treatments } \\
\text { (Moynihan et al., 2008). }\end{array}$ \\
\hline Bib. Citation & $\begin{array}{l}\text { Moynihan R, Doran E, Henry D. Disease Mongering Is Now Part of the Global Health DebatePLoS Med, 2008; 5(5):e106. doi:10.1371/journal. } \\
\text { pmed.0050106 }\end{array}$ \\
\hline $\mathrm{MeSH}$ & None \\
\hline Pubmed & 65 citations for "disease mongering" (first in 1994) \\
\hline Babelnet & $\begin{array}{l}\text { bn:02354871n } \\
\text { Disease mongering is a pejorative term for the practice of widening the diagnostic boundaries of illnesses, and promoting public awareness of such, in } \\
\text { order to expand the markets for those who sell and deliver treatments, which may include pharmaceutical companies, physicians, and other professional } \\
\text { or consumer organizations. }\end{array}$ \\
\hline DBPedia & http://dbpedia.org/page/Disease_mongering \\
\hline Q-Code & QD447 \\
\hline $\begin{array}{l}\text { Pref. Term } \\
\text { (PT) }\end{array}$ & Overscreening \\
\hline Syn & \\
\hline French PT & Surdépistage \\
\hline Spanish PT & Sobretamizaje \\
\hline $\begin{array}{l}\text { Portuguese } \\
\text { PT }\end{array}$ & Sobrerrastreamento \\
\hline Definition & $\begin{array}{l}\text { Overscreening, also called unnecessary screening, is the performance of medical screening without a medical indication to do so. Screening is a medical } \\
\text { test in a healthy person who is showing no symptoms of a disease and is intended to detect a disease so that a person may prepare to respond to it. } \\
\text { Screening is indicated in people who have some threshold risk for getting a disease, but is not indicated in people who are unlikely to develop a disease. } \\
\text { Overscreening is a type of unnecessary health care (Wikipedia). }\end{array}$ \\
\hline Bib. citations & $\begin{array}{l}\text { Torke AM, Schwartz PH, Holtz LR, Montz K, Sachs GA. Older Adults and Forgoing Cancer Screening: "I Think It Would Be Strange”. JAMA Intern Med. } \\
\text { 2013;173(7):526-531. doi:10.1001/jamainternmed.2013.2903. }\end{array}$ \\
\hline
\end{tabular}


Table 2. Continued...

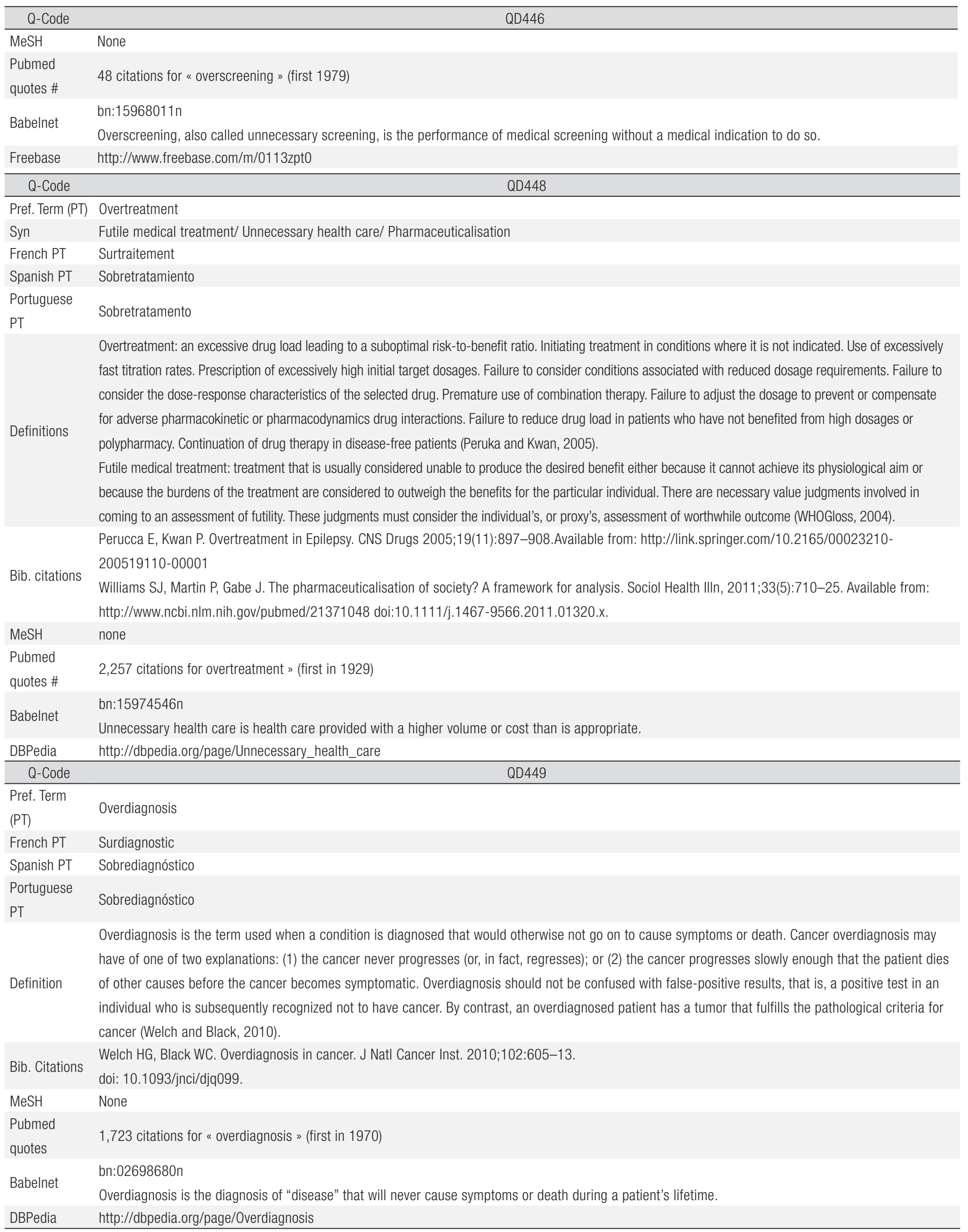




\section{Results}

The ten terms related to quaternary prevention are presented here in four languages with the links, definition(s) and their source(s) and bibliographic citation(s). Table 2 is completed by the corresponding MeSH, if any, with the MeSH definition, the count of the term in Pubmed (January 2015) and the date of first citation. Lastly, the links to Babelnet.org and Dbpedia are shown as the main connection to lay languages.

\section{Discussion}

Out of an ongoing research on the conceptual content of General Practice/Family medicine, 10 terms used by GPs in their conferences' communications have been analyzed in a terminological way with the help of a web based terminological graphic user interface. The particularity of the selected terms relates to the dangers of medicine and ethical duties of family doctors facing the epidemic of overmedicalization. Each of those ten terms is carefully related to the fourth field of prevention described in this special issue on $\mathrm{P} 4$.

Family doctors have to understand the basis and principles of overmedicalization, which encompass overinformation, overscreening, overdiagnosis, incidentaloma, disease mongering, and overtreatment. Each of those terms could imply the surge of possible Medically Unexplained Symptoms (MUS). For instance, shared decision making is one of the suggested tools to address the discrepancy between the doctor and the patient in the chaos described by Stacey, as quoted by Pisek $\&$ Greenhalgh, ${ }^{21}$ when disagreement meets uncertainty. Moreover, deprescription, more frequently referred to deprescribing, is another way to introduce quality assurance and control in the therapeutic process. In this sense, all the means dedicated to establish quaternary prevention are powerful tools to avoid the chaos and the terrible waste of resources either of human or economic, leading to a more sustainable health care by effectively implementing and maintaining of evidence-based policies and activities. ${ }^{22}$

The rules in terminological development aspire to cover the whole field of a concept and, in the meantime, they help to avoid the noise due to proxy and not exactly related issues. This refers to exhaustivity and specificity in information retrieval. "A great difficulty is that we cannot read the user's mind to acquire what he/she really wants" (p. 1). ${ }^{23}$ This exercise shows that referring to MeSH only in information retrieval in General Practice/Family medicine can induce much noise and poor adequacy to the subject investigated. Taking the search of 'Shared decision making' as an example, we could show much noise and unfruitful search. Indeed, the term 'Shared, decision making' is linked in the MesH thesaurus with the $\mathrm{MeSH}$ 'Decision making' whose use alone retrieve 123,265 entries. As the MeSH Decision making definition does not encompass the participation of the patient to the decision, the results obtained are not adequate. In this case, it is better to use the name of France Légaré, ${ }^{24}$ a well-known Canadian GP, researcher in this field, as author (Légaré F[Author]) to identify the main publications relevant to the process of participation of the patient and to follow the related citations in PubMed. This will ensure narrower, but more pertinent results in a bibliographic query.

The syntagm of Medically Unexplained symptoms, although quoted 958 times for medically unexplained symptoms (first 1980) and 239 times for medically unexplained symptom (first 1987), the last one on singular, has no corresponding entry in MeSH. The word overdiagnosis counts 1,723 citations (first in 1970) in Pubmed; overtreatment 2,257 citations (first in 1929); overscreening 48 citations (first 1979); disease mongering 65 citations (first in 1994), but have no corresponding entry $\mathrm{MeSH}$ as well.

Overmedicalization poses different issues as we could use Conrad's definition by adding the qualifier 'ethics' to find back the ongoing meaning of the word overmedicalization. Also, its counting in Medline varies according to its orthographic typing with the European way - overmedicalisation with ' $S$ ' - reflecting more the quaternary prevention mode of the phenomenon. It is important to highlight that overmedicalization and overtreatment refer both to unnecessary health care. This broad category is coming through Babelnet quotations from Wikipedia categorization process. Indeed, the choice of Wikipedia has been to class all the above analyzed terms in the broad category of unnecessary health care. ${ }^{25}$ Interestingly, all the ten terms are shared by lay terms terminologies as Babelnet of DBpedia, reflecting the interest of patients and general public for those problems, which are clearly at the meeting point of medicine with the public. 
Naturally, all those terms reflecting overutilization and waste of resources have to be complemented by the careful analysis of their counterparts: undermedicalization, undertreatment, underscreening. These are the natural companion of the analyzed terms. Unfortunately, market driven forces are prevalent, and consequently, the trend is in the direction of overmedicalization or wrong medicalization, which occurs in low-income countries, as well.

\section{Conclusion}

It is possible to argue that the definitions proposed here are up to only one author and that careful search in published literature could retrieve more appropriate citations. Nevertheless, a lot of colleagues, acknowledged above, have contributed to this work, by spontaneous exchanges through the P4 mailing lists ${ }^{26}$ between Europe and mainly South America. This is an open field of research and this paper is only a provocative appeal to invest more in specific terminological work dedicated to family medicine and primary care. Terminologies are evolutionary by essence and require to be adjusted to the need of corresponding domains of the researchers. They need also to be collaborative and this paper represents only a first step, a first call for more insights on methodological research in terminological field.

\section{Acknowledgements}

Special thanks to Niels Bentzen, emeritus professor of general practice in Trondheim, Norway and Wonca International Classification Committee past chair; and to Arthur Treuherz, chief terminologist at BIREME, the Latin-American and Caribbean Center on Health Sciences Information of the Pan American Health Organization in São Paulo, for their kind remark and help.

\section{References}

1. Eco U. Experiences in translation. University of Toronto Press: Scholarly Publishing Division; 2000. 112 p.

2. Moffett J. Teaching the universe of discourse. Boston: Houghton Mifflin Company; 1967.

3. Ben Abacha A, Zweigenbaum P. Automatic extraction of semantic relations between medical entities: a rule based approach. J Biomed Semantics. 2011;2(Suppl 5):S4. http://dx.doi.org/10.1186/2041-1480-2-S5-S4. PMid:22166723.

4. Jamoulle M. Q-Codes, authority list of non-clinical descriptors in GP/FM. Version 20150221. [cited 2015 June 17] Available from: http://docpatient.net/3CGP/Q-codes_4_languages.htm

5. De Vito EL. Quaternary prevention, a term not yet included in the Medical Subject Heading (MESH). Medicina (B Aires). 2013;73(2):187-190. PMid:23570772.

6. Morgan DJ, Wright SM, Dhruva S. Update on medical overuse. JAMA Intern Med. 2015;175(1):120-124. PMid:25365707.

7. Rouen Institute for Research and Innovation in Biomedicine. Research Team EA 4108-TIBS: Group TIBS. LITIS. 2012. [cited 2015 Jun 17]. Available from: http://irib.univ-rouen.fr/index.php?info=entites\&id=54.

8. Grosjean J, Griffon N, Dahamna B, Darmoni S. Multiterminology cross-lingual model to create the European health terminology. In: Proceedings of the 9th International Conference on Terminology and Artificial Intelligence; 2011. Paris: Institut National des Langues et Civilisations Orientales; 2011. p. 119-122.

9. Jamoulle M, Cardillo E, Roumier J, Warnier M, Vander Stichele R. Mapping French terms in a Belgian guideline on heart failure to international classifications and nomenclatures: the devil is in the detail. Inform Prim Care. 2014;21(4):189-198. http://dx.doi.org/10.14236/jhi.v21i4.66. PMid:25479349.

10. Navigli R, Ponzetto SP. BabelNet: The automatic construction, evaluation and application of a wide-coverage multilingual semantic network. Artif Intell. 2012;193:217-250. http://dx.doi.org/10.1016/j.artint.2012.07.001.

11. Yamamoto Y, Yamaguchi A, Yonezawa A. Building Linked Open Data towards integration of biomedical scientific literature with DBpedia. J Biomed Semantics. 2013;4(1):8. http://dx.doi.org/10.1186/2041-1480-4-8. PMid:23497538.

12. Lehmann, J, Isele, R, Jakob, M, Jentzsch, A, Kontokostas D, Mendes PN, et al. DBpedia-A large-scale, multilingual knowledge base extracted from Wikipedia. Semant Web. 2015;6:167-195. http://dx.doi.org/10.3233/SW-140134.

13. Bizer C, Heath T, Berners-Lee T. Linked Data-the story so far. Int J Semantic Web Inf Syst. 2009;5(3):1-22. http://dx.doi.org/10.4018/ jswis.2009081901. 
14. Maskalyk J. Modern medicine comes online: how putting Wikipedia articles through a medical journal's traditional process can put free, reliable information into as many hands as possible. Open Med. 2014;8(4):e116-e119. PMid:25426179.

15. Jiang G, Solbrig HR, Chute CG. Using semantic web technology to support icd-11 textual definitions authoring. J Biomed Semantics. $2013 ; 4(1): 11$. http://dx.doi.org/10.1186/2041-1480-4-11. PMid:23601451.

16. Jamoulle M. Attempt to classify main descriptors of GP/FM job. Proposal for a metaclinical classification. In: Proceedings of the Wonca Europe Conference; 2007. Paris, France: Wonca Europe; 2007. 502 p.

17. Jamoulle M. Or25 using ICPC and the core content Classification For General Practice (3CGP) to index Wonca Lisbon abstracts. In: Proceedings of the Wonca Europe Conference; 2014. Lisbon, Portugal: Wonca Europe; 2014.

18. Jamoulle M. Using the International Classification for Primary Care (ICPC) and the Core Content Classification for General Practice (3CGP) to classify conference abstracts. Rev Port Med Geral Fam. 2013; 29(5):66-67.

19. Wikipedia. Web ontology language. 2015 May 21 [cited 2015 Jun 17]. Available from: http://en.wikipedia.org/wiki/Web_Ontology_Language.

20. Cheung K-H, Prud'hommeaux E, Wang Y, Stephens S. Semantic web for health care and life sciences: a review of the state of the art. Brief Bioinform. 2009;10(2):111-113. http://dx.doi.org/10.1093/bib/bbp015. PMid:19304871.

21. Plsek PE, Greenhalgh T. Complexity science: The challenge of complexity in health care. BMJ. 2001;323(7313):625-628. http://dx.doi.org/10.1136/bmj.323.7313.625. PMid:11557716.

22. Schell SF, Luke DA, Schooley MW, Elliott MB, Herbers SH, Mueller NB, et al. Public health program capacity for sustainability: a new framework. Implement Sci. 2013;8(1):15. http://dx.doi.org/10.1186/1748-5908-8-15. PMid:23375082.

23. Tao X. Associate a user 's goal: exhaustivity and specificity information retrieval using ontology. In: Proceedings of the 4th International Conference on Active Media Technology (AMT06); 2006. Brisbane: Queensland University of Technology; 2006. p. 448-450. [cited 2015 Jun 17]. Available from: http://eprints.qut.edu.au/6030/1/6030_1.pdf.

24. Légaré F, Ratté S, Stacey D, Kryworuchko J, Gravel K, Graham ID, et al. Interventions for improving the adoption of shared decision making by healthcare professionals. Cochrane Database Syst Rev. 2010;(5):CD006732. PMid:20464744.

25. Wikipedia. Category: unnecessary health care. [cited 2015 Jun 17]. Available from: http://en.wikipedia.org/wiki/Category:Unnecessary_health_care.

26. Primary Health Care Classification Consortium (PH3C). Quaternary prevention. 2013 Dec 20 [cited 2015 Jun 17]. Available from: www.ph3c.org/P4. 